\title{
Chromosome number report of three Carex sect. Mitratae taxa (Cyperaceae) in Korea
}

\author{
Kyong-Sook CHUNG* and Hyoung-Tak IM ${ }^{1}$ \\ Department of Medicinal Plant Science, Jungwon University, Goesan 28024, Korea \\ ${ }^{\prime}$ Department of Biological Science, Chonnam National University, Gwangju 61186, Korea \\ (Received 3 August 2020; Revised 9 September 2020; Accepted 19 September 2020)
}

\begin{abstract}
We report meiotic chromosome numbers of three taxa in Carex sect. Mitratae in Korea: Carex breviculmis $\mathrm{R}$. Br. $\left(n=32_{\mathrm{II}}, 33_{\mathrm{II}}, 34_{\mathrm{II}}\right)$, C. polyschoena H. Lév. \& Vaniot ( $\left.n=37_{\mathrm{II}} 38_{\mathrm{II}}\right)$, and C. sabynensis Less. ex Kunth $\left(n=27_{\text {II }}\right)$. Section Mitratae is one of the most species-rich Asian groups in Carex, comprising approximately 45-80 taxa. Twenty-seven of these occur in Korea, and they are some of the most challenging taxa to identify due to their obscure and inconspicuous diagnostic characters. Including the counts reported here, half of the native Korean sect. Mitratae chromosome numbers have been documented. Their haploid chromosome numbers range from $n=10$ to $n=40$, and many exhibit variations in the numbers counted within a taxon. These variations, along with the overall significant variation in sect. Mitratae, suggest that dynamic chromosome activity may be related to the high species diversity of Carex.
\end{abstract}

Keywords: Carex, chromosome, Carex sect. Mitratae, Cyperaceae

Carex sect. Mitratae Kükenthal (Cyperaceae) comprises 4580 taxa, occurring in Asia, Australia, Europe, and New Zealand with high species diversity in East Asia (Tang et al., 2010; Hoshino et al., 2011). The section is characterized by a single, terminal spike inflorescence, tri- or di-stigmas, and membranous perigynia enclosing trigonous achenes with annulate or beak-like features at their apices (Tang et al., 2010; Nam, 2017). In Korea, there are about 180 Carex taxa in 43 sections, and sect. Mitratae is the largest one with 27 taxa, including one endemic, $C$. sabynensis Less. ex Kunth var. leiosperma Ohwi (Park et al., 2016; Nam, 2017). They grow sunny, wet places in forests and roadsides and bloom in early spring (Hoshino et al., 2011; Park et al., 2016).

Chromosome numbers dramatically vary in Carex, ranging from $n=6$ to $n=66$ (Tanaka, 1949; Roalson, 2008). Chromosomes in Cyperaceae are holocentric and lack localized centromeres. Holocentric chromosomes have spindle fibers attached along the entire length of the chromosome arms and viable fragments can be increased (fission, agmatoploidy) and/or decreased (fusion, symploidy) without DNA duplication/deletion events
(Malheiros-Gardé and Gardé, 1950; Luceño, 1994; Luceño and Guerra, 1996; Hipp et al., 2013). Due to these features, continuous chromosome number variation in Carex can result from either agmatoploidy/symploidy or aneuploidy (Luceño and Guerra, 1996; Hipp et al., 2009; Chung et al., 2011). Chromosome evolution plays an important role in the species richness of Carex, which is the most diverse flowing plant genus in temperate zones with more than 5,000 taxa worldwide (Hipp et al., 2009; Global Carex Group, 2015).

Many members of sect. Mitratae have variation in chromosome numbers within taxa, and univalent, trivalent, and/ or quadrivalent chromosomes are observed in some species such as Carex caryophyllea Latourr. and C. umbrosa Host subsp. huetiana (Boiss.) Soó (Luceño, 1993; Chung et al., 2016). Recently, meiotic chromosome numbers from Korean populations in the section have been reported: C. breviculmis R. Br. ( $n=33_{\text {II }}$ ) (Chung et al., 2017, 2018), C. fernaldiana H. Lév. \& Vaniot ( $n=33_{\text {II }}$ ) (Chung and Im, 2019), C. polyschoena H. Lév. \& Vaniot ( $n=26_{\text {II }}, 36_{\text {II }}, 37_{\text {III }}$ ) (Chung et al., 2016, 2018), C. sabynensis Less. ex Kunth ( $n=27_{\text {II }}, 28_{\text {II }}, 38_{\text {II }}$ ) (Chung

\footnotetext{
*Author for correspondence: kchung@jwu.ac.kr
} 
et al., 2016, 2017, 2018), and C. tristachya Thunb. ( $\left.n=21_{\text {II }}\right)$ (Chung et al., 2016, 2017). C. polyschoena and C. sabyenesis, common early-spring bloomers, exhibit high variation in chromosome number.

In the present study, we report additional chromosome numbers of three common sect. Mitratae taxa in Korea, Carex breviculmis, $C$. polyschoena, and $C$. sabynensis. These are the most common and widely distributed Mitratae species. Chromosome numbers reported for Korean taxa in the section are also documented.

\section{Materials and Methods}

Immature male spikes of Carex breviculmis, C. polyschoena, and $C$. sabynensis were fixed for meiotic chromosome number observation, following the methods of Rothrock and Reznicek (1996) and Chung et al. (2016). Spikes (terminal spikes in Carex sect. Mitratae) with immature anthers were preserved in a mixture of methanol, chloroform, and propionic acid (6:3:2) and then transferred to $70 \%$ ethanol. Fixed anthers were squashed in $1 \%$ acetic-orcein and observed at $1,000 \times$ magnification (Nikon Eclipse 50i, Nikon, Tokyo, Japan). More than two meiotic division cells per individual were observed and photographed. Voucher specimens with mature perigynia were collected and identified following Hoshino et al. (2011) and Park et al. (2016). The vouchers were deposited at
Chonnam National University herbarium (CNU, department of division of biological science).

\section{Results and Discussion}

Meiotic chromosome numbers of three taxa in Carex sect. Mitratae were observed (Table 1). Both $C$. breviculmis and $C$. polyschoena exhibited variation in chromosome numbers within the taxon and/or individual. Four individuals of $C$. breviculmis exhibited continuous variation in chromosome numbers, from $n=32_{\mathrm{II}}$ to $n=34_{\mathrm{II}}$. Two $C$. polyschoena individuals also had variation with $n=37_{\text {II }}$ and $38_{\text {II }}$. C. sabynensis had the meiotic chromosome number of $27_{\mathrm{II}}$. Their chromosomes were very small less than $2 \mu \mathrm{m}$ long, and constricted centromeres were not visible (Fig. 1).

\section{Carex breviculmis R. Br. $\left(n=32_{\|}, 33_{\|}, 34_{\|}\right)$(Fig. 1A-E)}

One count of $n=32_{\text {II, }}$ one count of $n=33_{\text {II }}$, and two counts of $n=34_{\text {II }}$ were observed in C. breviculmis (Fig. 1A-E). The counts made in the present work were identical to those in Tanaka (1939), Hoshino (1981), Ohkawa and Yokota (1998), de Lange and Murray (2002), and Chung et al. (2017, 2018). Following the taxonomic treatment of $C$. breviculmis (Park et al., 2016; Nam, 2017), previous chromosome counts for $C$. leucochlora were included in the species (Table 1). All the individuals examined were collected in sunny and open

Table 1. Carex sect. Mitratae taxa investigated with voucher specimens and chromosome numbers.

\begin{tabular}{|c|c|c|}
\hline Taxon (locality, voucher specimen) & $\begin{array}{l}\text { Chromosome } \\
\text { numbers } \\
\text { counted, } n\end{array}$ & Previous counts, $2 n$ \\
\hline \multicolumn{3}{|l|}{ C. breviculmis $\mathrm{R} . \mathrm{Br}$. } \\
\hline Anseo-dong, Cheonan-si, Chungnam (Chung 7013) & $34_{\text {II }}$ & 54 (Chung et al., 2016, reported as C. leucochlora) \\
\hline Sinbu-dong, Cheonan-si, Chungnam (Chung 7017) & $34_{\text {II }}$ & $\begin{array}{l}\text { c.64 (de Lange and Murray, 2002) } \\
66 \text { (Chung et al., 2017) }\end{array}$ \\
\hline Chilseong-myeon, Goesan-gun, Chungbuk (Chung 7029) & $33_{\text {II }}$ & $\begin{array}{l}66 \text { (Chung et al., 2018) } \\
64,68 \text { (Tanaka, } 1939 \text { cited from Roalson, 2008) }\end{array}$ \\
\hline Dongbu-ri, Goesan-eup, Goesan-gun, Chungbuk (Chung 7035) & $32_{\text {II }}$ & $\begin{array}{l}68 \text { (Hoshino, } 1981 \text { reported as C. leucochlora) } \\
68 \text { (Ohkawa and Yokota, } 1998 \text { reported as C. leucochlora) } \\
72 \text { (Okuno, } 1939 \text { cited from Roalson, 2008) }\end{array}$ \\
\hline \multicolumn{3}{|l|}{ C. polyschoena H. Lév. \& Vaniot } \\
\hline Chilseong-myeon, Goesan-gun, Chungbuk (Chung 7019) & $37_{\text {II }}$ & $\begin{array}{l}52 \text { (Chung et al., 2016) } \\
72,74 \text { (Chung et al., 2018) }\end{array}$ \\
\hline Dongbu-ri, Goesan-eup, Goesan-gun, Chungbuk (Chung 7032-1) & $37_{\mathrm{II}}, 38_{\mathrm{II}}$ & None \\
\hline \multicolumn{3}{|l|}{ C. sabynensis Less. ex Kunth } \\
\hline Anseo-dong, Cheonan-si, Chungnam (Chung 7009) & $27_{\mathrm{II}}$ & $\begin{array}{l}40 \text { (Krogulevich, 1971) } \\
54 \text { (Chung et al., 2016) } \\
54,56 \text { (Chung et al., 2018) } \\
60 \text { (Yurtsev and Zhukova, 1982) } \\
76 \text { (Chung et al., 2017) }\end{array}$ \\
\hline
\end{tabular}




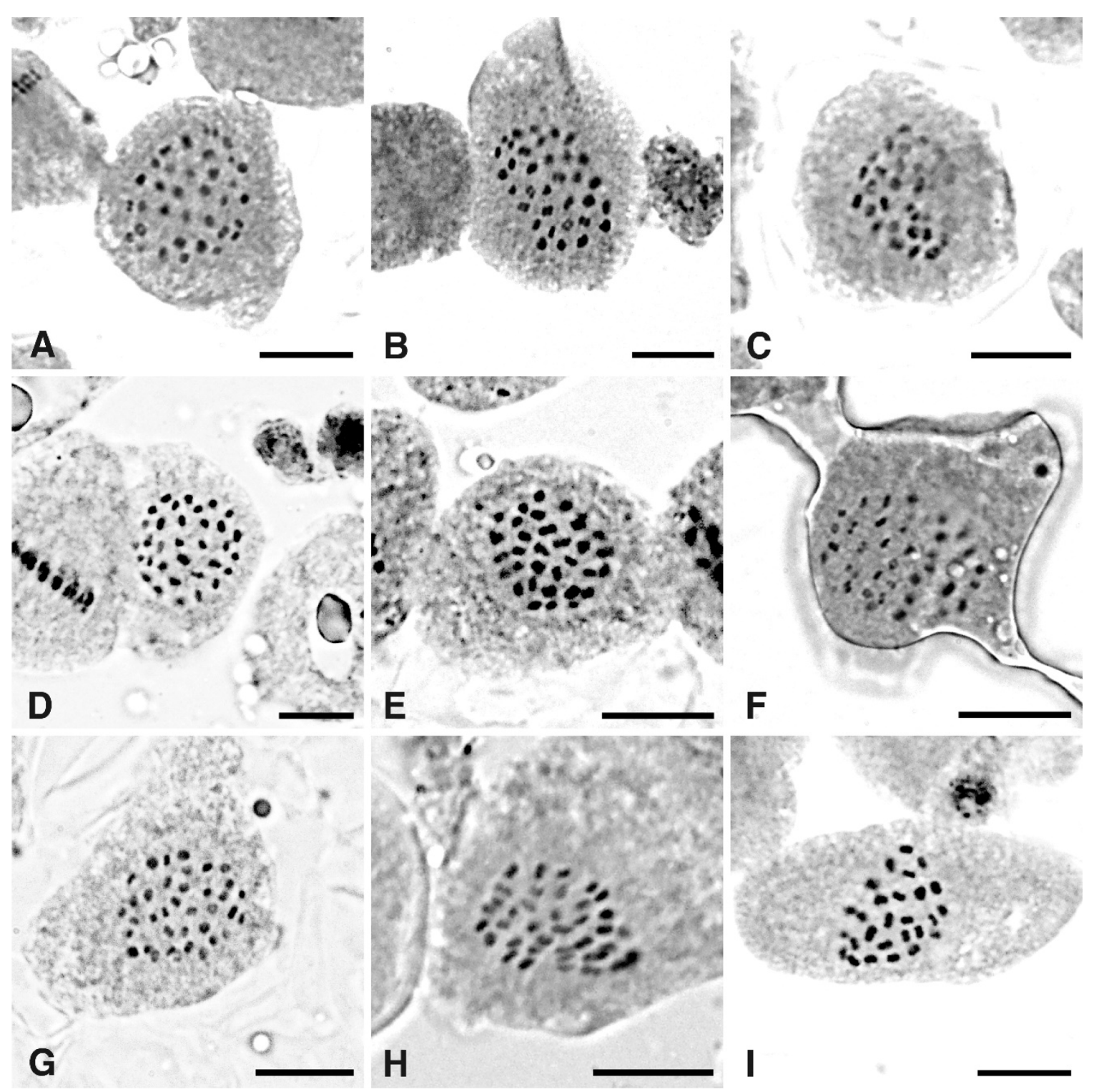

Fig. 1. Photomicrographs of Carex meiotic chromosomes. A-E. C. breviculmis. A, B. $n=34_{\text {II }}$ Chung 7013. C. $n=34_{I I}$, Chung 7017. D. $n=$ $33_{\text {II }}$, Chung 7029. E. $n=32_{\text {II }}$, Chung 7035. F-H. C. polyschoena. F. $n=37_{\text {III }}$ Chung 7019. G. $n=37_{\text {II }}$, Chung 7032. H. $n=38_{\text {II }}$, Chung 7032. I. C. sabynensis, $n=27_{\mathrm{II}}$, Chung 7009. Scale bars $=10 \mu \mathrm{m}$.

habitats. The species commonly occurs throughout the country. By the long awns on pistillate scales, pubescent perigynia, and terminal, staminate spikes without peduncles, C. breviculmis is distinguished from morphologically similar species such as C. mitrata var. aristata Ohwi (Park et al., 2016; Nam, 2017).

\section{Carex polyschoena H. Lév. \& Vaniot $\left(n=37_{\|,}, 38_{\|}\right)$} (Fig. 1F-H)

From two individuals two different meiotic chromosome numbers were observed, $n=37_{\text {II }}$ and the first report of $n=$ $38_{\text {II }}$ in the species (Fig. 1F-H). This new count expands the meiotic chromosome number variation range to $n=26_{\mathrm{II}}, 36_{\mathrm{II}}$, $37_{\text {II }}, 38_{\text {II }}$ (Chung et al., 2016, 2018). The species occurs in Japan, Korea, and China (Park et al., 2016). Although the species very common in Korea growing through the county, in Japan only a few populations are found only in Tsushima Island, Nagasaki Prefecture, where the holotype of species was collected (Hoshino et al., 2011). Tang et al. (2010) and Govaerts (2020) treated $C$. polyschoena as a synonym of $C$. pisiformis Boott, but Hoshino et al. (2011) recognized them as two independent species and considered $C$. pisiformis as an endemic species in Japan. In addition, Hoshino (1981) reported 
chromosome number of $2 n=68$ for $C$. pisiformis. More recently, two taxa are distinguished by rhizome, pistillate inflorescence shape, and perigynium beak characters (Nam, 2017). Species delimitation of the species C. polyschoena and $C$. pisiformis should be reexamined covering entire distribution areas of the species.

\section{Carex sabynensis Less. ex Kunth ( $\left.n=27_{\|}\right)$(Fig. 1I)}

Multiple cells from one individual of C. sabynensis constantly had a meiotic chromosome number of $n=27_{\text {II }}$ (Fig. 1I) as in Chung et al. (2016, 2018), which was also observed from Korean populations. Counts from other Korean individuals show variation with numbers of $n=27_{\text {II, }} 28_{\text {II, }} 38_{\text {II }}$ (Table 1).
The species occurs broadly in East Asia, and variation in chromosome number is evident throughout its range (Hoshino et al., 2011). The species was considered as a subspecies of C. umbrosa Host - C. umbrosa subsp. sabynensis (Less. ex Kunth) Kük Govaerts (2020). However, Nam (2017) treated C. sabynensis as an independent species based on distinct pistillate inflorescence and perigynium characters.

\section{Chromosome number variation in sect. Mitratae}

The chromosome numbers of half of native Korean sect. Mitratae taxa have been documented (Table 2). The haploid numbers range from $n=10$ (C. blepharicarpa Franch.) to $n$ $=40$ (C. stenostachys Franch. \& Sav.), and most taxa exhibit

Table 2. Chromosome numbers reported in Carex sect. Mitratae in Korea.

\begin{tabular}{|c|c|c|}
\hline Taxon & "Chromosome number, $2 n$ & Distribution \\
\hline $\begin{array}{l}\text { C. alterniflora var. rubrovaginata J. Oda } \\
\text { \& Nagam. }\end{array}$ & None & Japan, Korea \\
\hline C. blepharicarpa Franch. & $\begin{array}{l}\text { 30, } 32 \text { (Hoshino, 1981) } \\
\text { 26-33, } 41 \text { (Hoshino and Okamura, 1993) } \\
20 \text { (Lee and Kim, 2008) }\end{array}$ & Japan, Korea \\
\hline C. breviculmis $\mathrm{R} . \mathrm{Br}$. & $\begin{array}{l}72 \text { (Okuno, } 1939 \text { cited from Roalson, 2008) } \\
64,68 \text { (Tanaka, } 1939 \text { cited from Roalson, 2008) } \\
68 \text { (Hoshino, } 1981 \text { reported as C. leucochlora) } \\
68 \text { (Ohkawa and Yokota, } 1998 \text { reported as C. leucochlora) } \\
\text { c.64 (de Lange and Murray, 2002) } \\
54 \text { (Chung et al., 2016, reported as C. leucochlora) } \\
66 \text { (Chung et al., 2017) } \\
66 \text { (Chung et al., 2018) } \\
64,66,68 \text { (This study) }\end{array}$ & $\begin{array}{c}\text { Japan, China, Russia, } \\
\text { Nepal, India, } \\
\text { Myanmar, Taiwan, } \\
\text { Korea }\end{array}$ \\
\hline C. candolleana H. Lév. \& Vaniot & None & Japan, Korea \\
\hline C. conica Boott & $\begin{array}{l}\text { 34, 35, } 38 \text { (Tanaka, } 1938 \text { cited from Roalson, 2008) } \\
\text { 34, 38, } 42 \text { (Okuno, } 1939 \text { cited from Roalson, 2008) } \\
\text { 34, 35, } 38 \text { (Tanaka, } 1939 \text { cited from Roalson, 2008) } \\
\text { 34, } 38 \text { (Funabiki, } 1958 \text { cited from Roalson, 2008) } \\
\text { 32, } 36 \text { (Hoshino and Okamoto, 1979) } \\
\text { 32-38 (Hoshino, 1980) } \\
\text { 32, 34, 36-38 (Hoshino, 1981) } \\
\text { 32, 34, 36, } 38 \text { (Hoshino, 1989) }\end{array}$ & Japan, Korea \\
\hline C. fernaldiana H. Lév. \& Vaniot & $\begin{array}{l}\text { 66, 67, 68, } 72 \text { (Tanaka, } 1940 \text { cited in Roalson, } 2008 \text { as C. sachalinensis F. } \\
\text { Schmidt var. fernaldiana (H. Lév. \& Vaniot) T. Koyama) } \\
66 \text { (Chung and Im, 2019) }\end{array}$ & Japan, Taiwan, Korea \\
\hline C. fibrillosa Franch. \& Sav. & None & $\begin{array}{c}\text { Japan, China, Taiwan, } \\
\text { Korea }\end{array}$ \\
\hline C. genkaiensis Ohwi & None & Japan, Korea \\
\hline C. hypochlora Freyn & None & China, Russia, Korea \\
\hline C. kamagariensis K. Okamoto & None & Japan, Korea \\
\hline C. matsumurae Franch. & $\begin{array}{l}66 \text { (Okuno, } 1939 \text { cited in Roalson, 2008) } \\
64 \text { (Hoshino, 1981) }\end{array}$ & Japan, Korea \\
\hline C. meridiana (Akiyama) Akiyama & None & Japan, Korea \\
\hline C. microtricha Franch. & 30-32 (Probatova et al., 2004) & Japan, Korea \\
\hline
\end{tabular}


Table 2. Continued.

\begin{tabular}{|c|c|c|}
\hline Taxon & Chromosome number, $2 n$ & Distribution \\
\hline C. mitrata Franch. var. mitrata & None & $\begin{array}{l}\text { Japan, China, Taiwan, } \\
\text { Korea }\end{array}$ \\
\hline C. mitrata var. aristate Ohwi & None & $\begin{array}{c}\text { Japan, China, Taiwan, } \\
\text { Korea }\end{array}$ \\
\hline C. multifolia Ohwi & $\begin{array}{l}30 \text { (Okuno, } 1939 \text { cited in Roalson, } 2008 \text { as C. dolichostachya Hayata) } \\
\text { 30, 60, 64-66 (Tanaka, } 1940 \text { cited in Roalson } 2008 \text { as C. dolichostachya } \\
\text { Hayata) } \\
\text { 30, 60, 64-66, } 70 \text { (Funabiki, } 1958 \text { cited in Roalson } 2008 \text { as C. } \\
\text { dolichostachya Hayata) } \\
70 \text { (Hoshino, 1981) }\end{array}$ & Japan, Korea \\
\hline C. nervata Franch. \& Sav. & $\begin{array}{l}76 \text { (Okuno, } 1939 \text { cited in Roalson, 2008) } \\
76 \text { (Tanaka, } 1939 \text { b cited in Roalson, 2008) }\end{array}$ & Japan, Russia, Korea \\
\hline C. pocilliformis Boott & $\begin{array}{l}\text { 38, } 40 \text { (Hoshino, 1981a cited in Roalson, } 20008 \text { as C. tristachya Thunb. } \\
\text { var. pocilliformis (Boott) Kük.) } \\
39 \text { (Ohkawa and Yokota, 1998) }\end{array}$ & $\begin{array}{c}\text { Japan, China, Taiwan, } \\
\text { Korea }\end{array}$ \\
\hline C. polyschoena H. Lév. \& Vaniot & $\begin{array}{l}52 \text { (Chung et al., 2016) } \\
72,74 \text { (Chung et al., 2018) } \\
74,76 \text { (this study) }\end{array}$ & Japan, Korea \\
\hline C. rugata Ohwi & None & $\begin{array}{l}\text { Japan, China, Taiwan, } \\
\text { Korea }\end{array}$ \\
\hline C. sabynensis var. sabynensis & $\begin{array}{l}40 \text { (Krogulevich, 1971) } \\
60 \text { (Yurtsev and Zhukova, 1982) } \\
54 \text { (Chung et al., 2016) } \\
76 \text { (Chung et al., 2017) } \\
54,56 \text { (Chung et al., 2018) } \\
54 \text { (this study) }\end{array}$ & $\begin{array}{c}\text { Japan, China, Russia, } \\
\text { Korea }\end{array}$ \\
\hline C. sabynensis var. leiosperma Ohwi & None & Korea \\
\hline C. stenostachys Franch. \& Sav. & $\begin{array}{l}58 \text { (Hoshino, 1981) } \\
80 \text { (Yurtsev and Zhukova, } 1978 \text { cited in Roalson, 2008) } \\
58-60 \text { (Hoshino et al., 1993) } \\
\text { 58-61 (Hoshino et al., } 1994 \text { cited in Roalson, 2008) }\end{array}$ & Japan, Korea \\
\hline C. subebracteata (Kük.) Ohwi & None & $\begin{array}{l}\text { Japan, China, Russia, } \\
\text { Korea }\end{array}$ \\
\hline C. toyoshimae Tuyama & 62 (Yano, 2006) & Japan, Korea \\
\hline C. tristachya Thunb. & $\begin{array}{l}42 \text { (Chung et al., 2016) } \\
42 \text { (Chung et al., 2017) }\end{array}$ & Japan, China, Korea \\
\hline C. tsuhimensis (Ohwi) Ohwi & None & Japan, Korea \\
\hline
\end{tabular}

variation in their chromosome numbers. Among the fourteen taxa, only three have consistent chromosome numbers: $C$. nervata Franch. \& Sav. $(2 n=76), C$. toyoshimae Tuyama $(2 n$ $=62)$, and $C$. tristachya Thunb. $(2 n=42)$. In contrast, $C$. multifolia Ohwi exhibits the broadest range of variation $(2 n=$ $30,60,64-66,70)$. Because chromosome variation in Carex provides important information on taxonomy as well as genetic diversity, it is encouraged to investigate additional individuals of every taxon (Hoshino et al., 1993; Hip et al., 2010).

Positive correlations between chromosome number and genetic diversity and geographic distance have been found (Luceño and Castroviejo, 1991; Hipp et al., 2010). Varying chromosome numbers might reflect genetic diversity within and/or among individuals in a taxon but also might result from incongruent hypotheses on species delimitations among researchers. Previous taxonomic studies were limited to certain geographic areas, such as China (Tang et al., 2010) and Japan (Hoshino et al., 2011). Comprehensive systemic research targeting the section's entire geographic range are needed. In addition, laboratory and/or biological errors might present. For 
instance, somatic metaphase chromosome number of $C$. blepharicarpa Franch. reported by Lee and Kim (2008) is $2 n$ $=20$, but many chromosomes are overlapping each other in the image and seem to be considered as mono-centromere chromosomes by the authors. It could be $2 n=$ about 40 . All the voucher specimens and raw chromosome data should be available to researchers, so that critical cytological data of Carex, taxonomically challenging taxa, are well-documented for further research on phylogeny and evolution.

ORCID: Kyong-Sook CHUNG https://orcid.org/0000-00024464-4698; Hyoung-Tak IM https://orcid.org/0000-0002-63336244

\section{Acknowledgments}

We thank Amy Buthod (Robert Bebb Herbarium, University of Oklahoma) for comments on an earlier version of the manuscript.

\section{Conflict of Interest}

The authors declare that there are no conflicts of interest.

\section{Literature Cited}

Chung, K.-S. and H.-T. Im. 2019. Report on the chromosome numbers of four Carex taxa (Cyperaceae). Korean Journal of Plant Taxonomy 49: 269-273.

Chung, K.-S., T. Hoshino, T. Masaki and H.-T. Im. 2017. Cytological investigations on eight Carex species in Korea (Cyperaceae). Cytologia 82: 329-334.

Chung, K.-S., T. Hoshino, T. Masaki, H.-T. Im and S.-J. Ji. 2018. Chromosome counts of six Korean Carex species (Cyperaceae). Cytologia 83: 229-233.

Chung, K.-S., T. Hoshino, T. Masaki, J. C. Yang and H.-T. Im. 2016. Cytological studies on seven species of Korean Carex (Cyperaceae). Cytologia 81: 143-147.

Chung, K.-S., J. A. Weber and A. L. Hipp. 2011. The dynamics of chromosome and genome size variation in a cytogenetically variable sedge (Carex scoparia var. scoparia, Cyperaceae). American Journal of Botany 98: 122-129.

de Lange, P. J. and B. G. Murray. 2002. Contributions to a chromosome atlas of the New Zealand flora: 37. Miscellaneous families. New Zealand Journal of Botany 40: 1-23.

Global Carex Group. 2015. Making Carex monophyletic (Cyperaceae, tribe Cariceae): a new broader circumscription. Botanical Journal of the Linnean Society 179: 1-42.
Govaerts, R. 2020. World Checklist of Cyperaceae. Facilitated by the Royal Botanic Gardens, Kew. Published on the Internet. Retrieved Jul. 15, 2020, available from http://wcsp.science.kew.org/.

Hipp, A. L., M. Escudero and K.-S. Chung. 2013. Holocentric chromosomes. In Encyclopedia of Genetics. 2nd ed. Vol. 3. Maloy, S. and K. Hughes (eds.), Elsevier, New York. Pp. 499501.

Hipp, A. L., P. E. Rothrock and E. H. Roalson. 2009. The evolution of chromosome arrangements in Carex (Cyperaceae). The Botanical Review 75: 96-109.

Hipp, A. L., P. E. Rothrock, R. Whitkus and J. A. Weber. 2010. Chromosomes tell half of the story: the correlation between karyotype rearrangements and genetic diversity in sedges, a group with holocentric chromosomes. Molecular Ecology 19: 3124-3138.

Hoshino, T. 1980. Morphological and cytogenetic studies on the aneuploidy in Carex conica Bott. The Bulletin of the Hiruzen Research Institute 4-5: 33-38.

Hoshino, T. 1981. Karyomorphological and cytogenetical studies on aneuploidy in Carex. Journal of Science of the Hiroshima University, Series B Division 2 17: 155-238.

Hoshino, T. 1989. Cytogenetical studies on aneuploidy in Carex (Cyperaceae). In Plant Chromosome Research 1987. Hong, D. (ed.), Beijing. Pp. 55-60.

Hoshino, T. and K. Okamoto. 1979. Geographical distribution of two cytotypes of Carex conica in Seto Inland Sea area of Japan. Journal of Japanese Botany 54: 185-189.

Hoshino, T. and K. Okamura. 1993. Meiotic chromosome configurations of intraspecific aneuploids in Carex blepharicarpa. In XV International Botanical Congress; 23-27 Aug 1993; Tokyo, Japan. P. 208.

Hoshino, T., K. Aosaki and A. Onimatsu. 1993. Cytological studies of Carex stenostachys (Cyperaceae) with special references to meiotic configurations of intraspecific aneuploids. La Kromosoma II 71-72: 2451-2455.

Hoshino, T., T. Masaki and M. Nishimoto. 2011. Illustrated Sedges of Japan. Heibonsha Ltd., Tokyo. Pp. 270-379.

Krogulevich, R. E. 1971. The role of polyploidy in the genesis of the alpine flora of the Stanovoye Nagorye Mountains. In The Ecology of the Flora of the Trans-Baikal Region. Krogulevich, R. E. and A. A. Gorshkov (eds.), USSR Academy of Sciences, Irkutsk. Pp. 115-214.

Lee, J. and S. Y. Kim. 2008. Chromosomes of Endemic Plants in Korea 2008. Korea Research Institute of Bioscience and Biotechnology, Daejeon. P. 16.

Luceño, M. 1993. Chromosome studies on Carex L. section Mitratae Kükenth. (Cyperaceae) in the Iberian Peninsula. Cytologia 
58: 321-330.

Luceño, M. 1994. Cytotaxonomic studies in Iberian, Balearic, North African, and Macaronesian species of Carex (Cyperaceae): II. Canadian Journal of Botany 72: 587-596.

Luceño, M. and S. Castroviejo. 1991. Agmatoploidy in Carex laevigata (Cyperaceae): fusion and fission of chromosomes as the mechanism of cytogenetic evolution in Iberian populations. Plant Systematics and Evolution 177: 149-159.

Luceño, M. and M. Guerra. 1996. Numerical variations in species exhibiting holocentric chromosomes: a nomenclatural proposal. Caryologia 49: 301-309.

Malheiros-Gardé, N. and A. Gardé. 1950. Chromosome number in Luzula multiflora Lej. Genét Ibér 4: 91-94.

Nam, G.-H. 2017. A systematic study of the genus Carex sect. Mitratae (Cypearaceae) in Korea. $\mathrm{PhD}$ dissertation, Andong National University, Andong. Pp. 1-7, 90-206. (in Korean)

Ohkawa, T. and M. Yokota. 1998. Chromosome numbers and their variation patterns of Carex in the Ryukyu Islands. Cytologia 63: 447-457.

Park, S.-H., Y.-M. Lee, H.-J. Kim, J.-C. Yang, C.-S. Jang, K.-H. Lee, J.-S. Lee, J.-S. Han, H.-J. Kim, K.-S. Jeong, D.-C. Son, D.-H. Lee, M.-J. Joo, E.-M. Sun, C.-H. Shin, K. Choi, S.-H. Oh, K. S. Chang, S.-Y. Jung and S.-J. Ji. 2016. Illustrated Cyperaceae of Korea. Munyoungsa, Seoul. Pp. 10-13, 170211.

Probatova, N. S., V. Y. Barkalov and E. G. Rudyka. 2004. Chro- mosome numbers of selected vascular plant species from Sakhalin, Moneron and the Kurile Islands. Biodiversity and Biogeography of the Kuril Islands and Sakhalin 1: 15-23.

Roalson, E. H. 2008. A synopsis of chromosome number variation in the Cyperaceae. Botanical Review 74: 209-393.

Rothrock, P. E and A. A. Reznicek. 1996. Documented chromosome numbers 1996:1. Chromosome numbers in Carex section Ovales (Cyperaceae) from Eastern North America. Sida 17: 251-258.

Tanaka, N. 1939. Chromosome studies in Cyperaceae IV. Chromosome number of Carex species. Cytologia 10: 51-58.

Tanaka, N. 1949. Chromosome studies in the genus Carex with special reference to aneuploidy and polyploidy. Cytologia 15 : $15-29$.

Tang, Y., S. Zhang, T. Koyama, and G. C. Tucker. 2010. Carex sect. Mitratae Kükenthal. In Flora of China, Vol. 23. Acoraceae through Cyperaceae. Wu, Z., P. H. Raven, and D. Hong (eds.), Science Press, Beijing and Missouri Botanical Garden Press, St. Louis, MO. Pp. 320-329.

Yano, O. 2006. Cytological studies of seven taxa of Cyperaceae collected from the Bonin (Ogasawara) Islands. Journal of Japanese Botany 81: 98-102.

Yurtsev, B. A. and P. G. Zhukova. 1982. Chromosome numbers of some plants of the northeastern Yakutia (the drainage of the Indigirka River in its middle reaches). Botanicheskii Zhurnal 67: 778-787. 